\title{
EXODONTIA DE CANINO SUPRANUMERÁRIO MANDIBULAR INCLUSO
}

Eron Fernandes MARQUES, Franciele Borba POTULSKI, Celso YAMASHITA

A existência de dente supranumerário traduz um excesso no número de dentes, que pode ocorrer em ambas às dentições, são classificados de acordo com sua morfologia e localização. A presença desses dentes pode causar problemas, como falhas na erupção, deslocamento de dentes, apinhamento, cistos e tumores odontogênicos. O objetivo deste trabalho é descrever um caso clínico de extração de dente supranumerário não irrompido presente na região de canino mandibular esquerdo. Paciente M.J, sexo masculino, 14 anos, após exame radiográfico panorâmico e confirmada a hipótese diagnóstica de dente supranumerário incluso, através do exame de tomografia computadorizada obteve-se a localização do dente, definiu-se então que o elemento supranumerário estaria em posição vertical, seguindo o eixo do canino presente na arcada, com certa distância, não estando em contato com a raiz do dente já erupcionado. Para a extração cirúrgica, foi feito o retalho, descolado e protegido para não haver lacerações na mucosa, a remoção do osso para exposição coronária, osteotomia e então a retirada do elemento dental e suturado.

Palavras-chave: Extração Dentária; Dente Supranumerário; Dente nãoErupcionado. 